\title{
PROPERTIES OF SFRC WITH PARTIAL REPLACEMENT OF CEMENT \& SAND BY C.O.T \& I.O.T
}

\author{
Chaithanya M.B ${ }^{1}$, Shashi kumar N.V ${ }^{2}$, Narayana $^{3}$, B.K Narendra ${ }^{4}$ \\ ${ }^{1}$ Post Graduate student, Department of Civil Engineering, S.J.C.I.T, chickballapura, Karnataka, India \\ ${ }^{2}$ Assistant Professor, Department of Civil Engineering, S.J.C.I.T, chickballapura, Karnataka, India \\ ${ }^{3}$ Professor and Head of Department of Civil Engineering, S.J.C.I.T, chickballapura, Karnataka, India \\ ${ }^{4}$ Principal, Department of Civil Engineering, B.G.S.I.T, Bellur cross, Karnataka, India
}

\begin{abstract}
Most important problem facing mankind today is how best to utilize natural resources to meet human needs and nurture economic growth without exhausting the resources and endangering the environmental integral on which life economic prosperity and our security depend. Due to rapid growth of construction activity concreting materials became scarcity such as sand and cement, so alternative material such as iron ore tailing and copper ore tailing which is a waste produced in production of steel and copper is used as partial replacement as cement and sand respectively, and hence to avoid the environmental pollution. This experimental work is taken up to study the effect of volume replacement on concrete strength of concrete with different percentage replacement levels.

This experimental investigation deals characterization of materials including iron ore tailing and copper ore tailing. The properties of materials are incorporated in concrete mix design and mix design as per procedure mentioned in IS $1026-2009$. The fresh properties of the mixes and its hardened properties namely compressive strength for different curing periods of 3 , 7 and 28 days, tensile strength for curing period of 7, 14 and 28days, and flexural strength for curing period of 28 and 56 days are evaluated. Total eight different mixes viz 0\%, 15\%, 17.5\%, 20\%, 22.5\%, 25\%, 27.5\% and 30\% of replacements for both cement and sand with COT and IOT respectively, with $0.6 \%$ of steel fibres, for M20 grade of concrete. Total 192 specimens had casted, out of which 72 cube specimens for compressive strength, 72 cylinder specimens for tensile strength and 48 beam specimens for flexural strength.
\end{abstract}

Keywords: COT-Copper ore tailing, IOT-Iron ore tailing, Material properties, compressive strength, split Tensile strength, flexural strength, SFRC-Steel Fibre Reinforced concrete

\section{INTRODUCION}

The increasing demand for heavy construction material like steel and iron has resulted in the establishment of many iron ore mining companies. Iron Ore Tailing is a waste generated from the Iron Ore industry. It is a very fine aggregate residue resulting from the extraction of Iron from Iron Ore. The residue left after extraction is in the form of slurry. And copper ore tailing is residue resulted from the extraction of copper from copper ore and it shows some pozzolonic property with cement. Problems involved in the disposal of iron ore tailing and copper ore tailing are lack of space, technical problems, cost and environmental hazards. Usually the ore tailing is disposed of in the vicinity of plant as waste material over several hectares of valuable land leading to water and land pollution.

An attempt is made to use this copper ore tailing as an admixture in the preparation of fiber reinforced concrete by replacing the cement and sand by copper ore and iron ore tailing for sand in different percentages viz 15, 17.5, 20, $22.5,25,27.5$ and 30 With $0.6 \%$ of steel fibres. The fundamental property like compressive strength, tensile strength and flexural strength is determined. To utilize the copper ore tailings and iron ore tailings as a replacement to' cement and sand respectively in steel fiber reinforced concrete and hence avoiding environmental pollution

\section{MATERIALS}

- Cement For the study the OPC 53 grade which satisfies the requirements IS 8112-1989 specifications is taken

- Coarse Aggregate The crushed stone aggregates from local quarry are used. The Coarse aggregates used are of $20 \mathrm{~mm}$ and down size and the tests are done as per IS 383-1970 and 2386-1963 specifications

- $\quad$ Fine Aggregate: Locally available sand is used. The fundamental properties are tested and justified as per IS code 383-1970.

- Curing period (i) For Cubes - 3, 7 and 28 days. (ii) For cylinders $-7,14$ and 28days and (iii) beams -28 , and 56days.

- $\quad$ Steel Fibers Crimped steel fibers are obtained from Majix steel fibers, Bombay (M \& J international), with 140 aspect ratio.

- Water Ordinary portable water free from organic content, turbidity and salts is used. 
- Iron ore tailings The iron ore tailings are collected from Kuduremukh iron Ore Company, Chikmagalur District.

And as per the standard procedure These sample is oven dried at $100^{\circ} \mathrm{C}$ and detailed study characterization is carried out as fine aggregate in concrete as per relevant IS Code of Practice. The physical and chemical properties are given in table below.

Table -1: Physical properties of IOT

\begin{tabular}{|l|l|l|}
\hline 1. & Particle shape & Spherical \\
\hline 2. & Density & $14.5 \mathrm{KN} / \mathrm{m} 3$ \\
\hline 3. & Specific gravity & 3.21 \\
\hline 4. & Colour & Dark tan (Brown) \\
\hline 5. & Maximum dry density & $1.71 \mathrm{gm} / \mathrm{cc}$ \\
\hline 6. & Sieve analysis \\
\hline 7. & \multicolumn{2}{|l|}{ Sieve Size } \\
\hline & a) $4.75 \mathrm{~mm}$ & Percentage passing \\
\hline & b) $2.36 \mathrm{~mm}$ & 100 \\
\hline & c) $1.18 \mathrm{~mm}$ & 90 \\
\hline & d) 600 & 58.9 \\
\hline & e) $300 \mu \mathrm{m}$ & 38.2 \\
\hline & f) $150 \mu \mathrm{m}$ & 21.8 \\
\hline & g)Pan & 7.8 \\
\hline & Classification & 0.5 \\
\hline
\end{tabular}

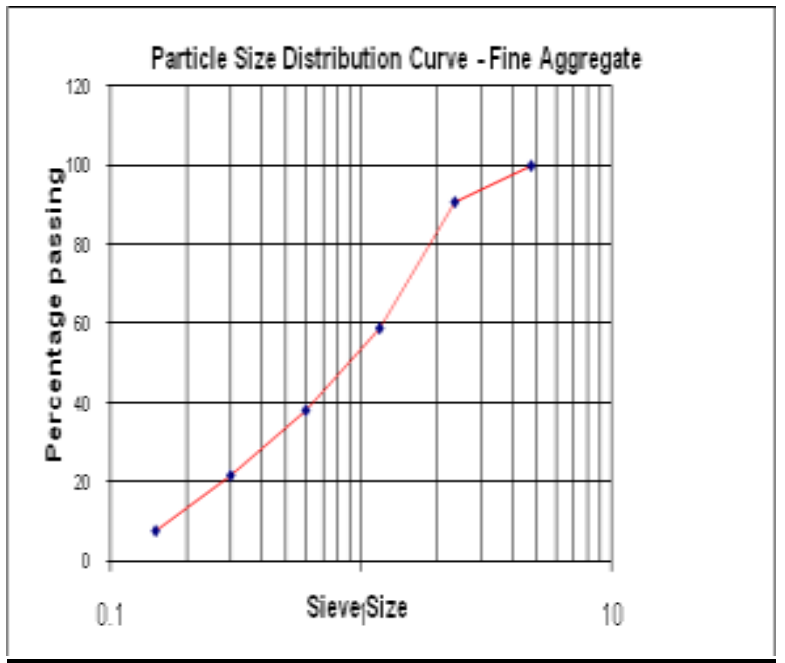

Chart -1: Partical size distribution for IOT

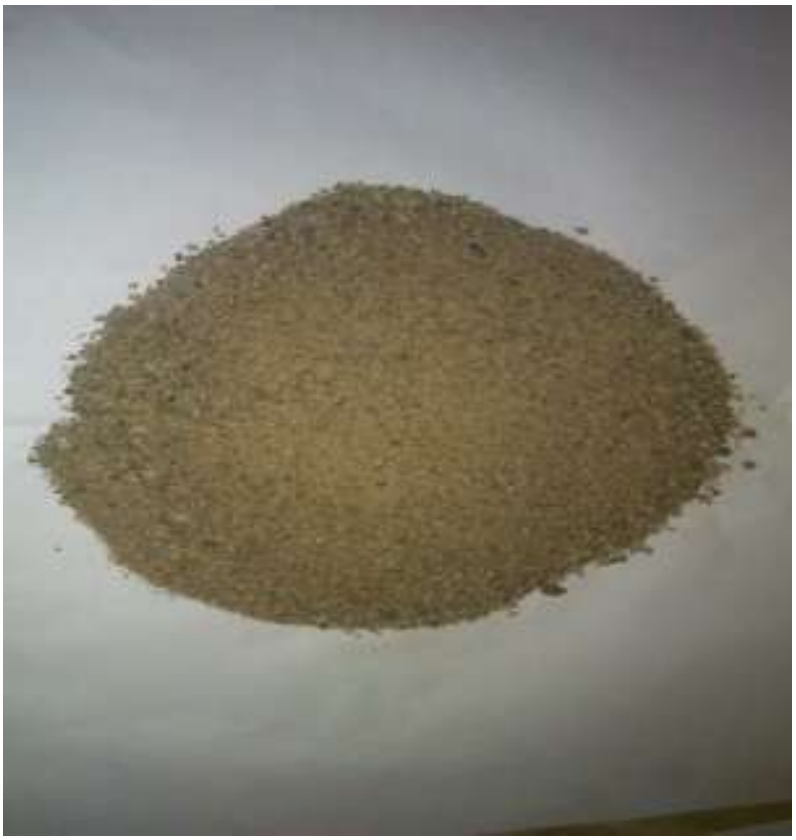

Fig -1: Iron ore tailing

Table -2: Chemical composition of IOT

\begin{tabular}{|l|l|}
\hline Constituent & Percentage \\
\hline Iron $(\mathrm{Fe})$ & 19 \\
\hline Silicon dioxide (SiO2) & 69 \\
\hline $\begin{array}{l}\text { Aluminium trioxide } \\
(\mathrm{A} 2 \mathrm{O} 3)\end{array}$ & 3 \\
\hline Manganese oxide $(\mathrm{MnO})$ & 0.20 \\
\hline Phosphorus $(\mathrm{P})$ & 0.04 \\
\hline Sulphur $(\mathrm{S})$ & 0.08 \\
\hline Titanic dioxide $(\mathrm{TiO} 2)$ & 0.10 \\
\hline Calcium oxide $(\mathrm{CaO})$ & 0.10 \\
\hline Magnesium oxide $(\mathrm{MgO})$ & 0.16 \\
\hline Sodium oxide $(\mathrm{Na} 2 \mathrm{O})$ & 0.06 \\
\hline Potassium oxide $(\mathrm{K} 2 \mathrm{O})$ & 0.04 \\
\hline Copper $(\mathrm{Cu})$ & 0.003 \\
\hline Nickel $(\mathrm{Ni})$ & 0.002 \\
\hline
\end{tabular}

- Copper ore tailings The copper ore tailings used in the experimental study was procured from Ingaldal copper mines, a unit of Hutti Gold Mines Company limited, Situated at a distance of $10 \mathrm{Km}$ from Chitradurga, Karnataka, under dry mode of condition. 


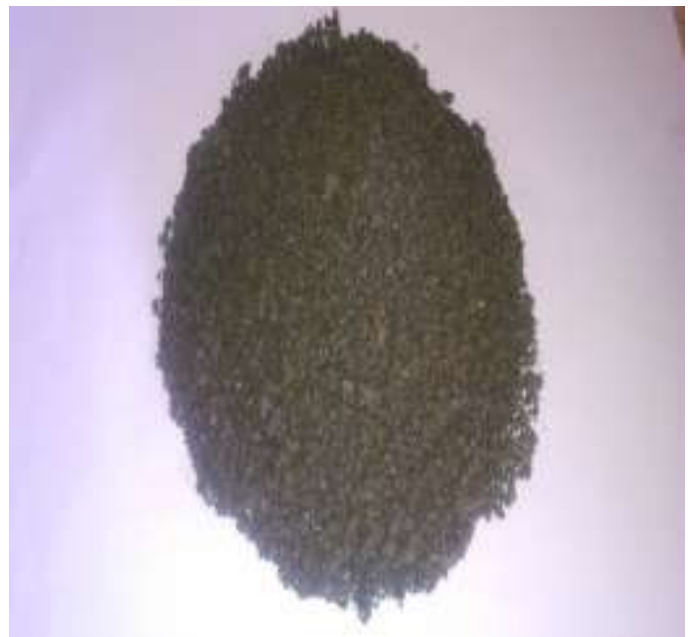

Fig -2: copper ore tailing.

characterization is done according to standard procedure charecterization of material is given in Table below.

Table -3: Chemical and physical properties of cement and copper ore tailings.

\begin{tabular}{|c|c|c|c|}
\hline \multicolumn{4}{|c|}{ Chemical composition (\%) } \\
\hline Component & Cement & \multicolumn{2}{|c|}{$\begin{array}{l}\text { Copper } \\
\text { tailing }\end{array}$} \\
\hline $\begin{array}{ll}\text { Silicon } & \text { dioxide } \\
(\mathrm{SiO} 2) & \end{array}$ & 29.15 & \multicolumn{2}{|l|}{11.20} \\
\hline $\begin{array}{l}\text { Aluminium trioxide } \\
(\mathrm{Al} 2 \mathrm{O} 3)\end{array}$ & 7.34 & \multicolumn{2}{|l|}{-} \\
\hline Iron oxide $(\mathrm{Fe} 2 \mathrm{O} 3)$ & 2.42 & \multicolumn{2}{|l|}{85.30} \\
\hline $\begin{array}{ll}\text { Calcium } & \text { oxide } \\
(\mathrm{CaO}) & \end{array}$ & 50.04 & \multicolumn{2}{|l|}{-} \\
\hline $\begin{array}{l}\text { Magnesium oxide } \\
(\mathrm{MgO})\end{array}$ & 3.99 & \multicolumn{2}{|l|}{-} \\
\hline $\mathrm{SO} 3$ & 1.97 & \multicolumn{2}{|l|}{-} \\
\hline $\mathrm{Cl}$ & 0.01 & \multicolumn{2}{|l|}{-} \\
\hline Loss on ignition & 1.65 & \multicolumn{2}{|l|}{-} \\
\hline Insoluble residue & 0.27 & \multicolumn{2}{|l|}{-} \\
\hline $\begin{array}{l}\text { Heavy metal } \\
\text { content }(\mathrm{mg} / \mathrm{kg})\end{array}$ & - & \multicolumn{2}{|l|}{-} \\
\hline $\mathrm{Cu}$ & - & \multicolumn{2}{|l|}{2284} \\
\hline $\mathrm{Zn}$ & - & \multicolumn{2}{|l|}{402} \\
\hline $\mathrm{Pb}$ & - & \multicolumn{2}{|l|}{60} \\
\hline $\mathrm{Cr}$ & - & \multicolumn{2}{|l|}{12} \\
\hline $\mathrm{Cd}$ & - & \multicolumn{2}{|l|}{0.86} \\
\hline \multicolumn{4}{|l|}{ Physical property } \\
\hline Specific gravity & \multicolumn{2}{|l|}{2.96} & 4.29 \\
\hline $\begin{array}{l}\text { Blain specific } \\
\text { surface area }\end{array}$ & \multicolumn{2}{|l|}{3440} & 537 \\
\hline Absorption(\%) & \multicolumn{2}{|l|}{-} & 13.82 \\
\hline
\end{tabular}

\section{RESULTS AND DISCUSSION}

This section introduces the aftereffects of the test examinations, in which aftereffects of droop test is exhibited first as new properties of cement took after by solidified properties of cement specifically compressive quality test, part pliable test and flexural test. The outcomes alongside the examination re accommodated every test independently.

\subsection{Workability}

Table -4: slump of different percentage replacement

\begin{tabular}{|l|l|l|l|}
\hline $\begin{array}{l}\text { Sl. } \\
\text { No }\end{array}$ & $\begin{array}{l}\text { Percentage } \\
\text { Replacements }\end{array}$ & $\begin{array}{l}\text { Water } \\
\text { cement } \\
\text { ratio }\end{array}$ & $\begin{array}{l}\text { Slump in } \\
\text { mm }\end{array}$ \\
\hline 1 & $0 \%$ & 0.5 & 100 \\
\hline 2 & $15 \%$ & 0.5 & 92 \\
\hline 3 & $17.5 \%$ & 0.5 & 88 \\
\hline 4 & $20 \%$ & 0.5 & 84 \\
\hline 5 & $22.5 \%$ & 0.5 & 78 \\
\hline 6 & $25 \%$ & 0.5 & 69 \\
\hline 7 & $27.5 \%$ & 0.5 & 60 \\
\hline 8 & $30 \%$ & 0.5 & 55 \\
\hline
\end{tabular}

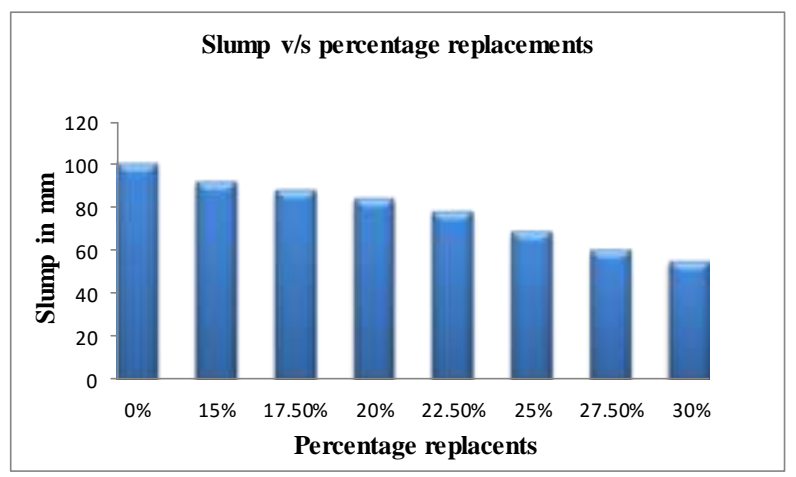

Chart -2: workability

From the result of slump test on different replacement levels of cement and sand with copper ore tailing and iron ore tailing in concrete are compared with the conventional concrete. It shows that as percentage replacement increases the slump goes on decreasing, hence for the given slump, replacement level increases percentage of water addition is also increased.

\subsection{Compressive strength}

Table -5: Details of average compressive strength for 3, 7, and 28 days

\begin{tabular}{|c|c|c|c|}
\hline \multirow[t]{2}{*}{$\begin{array}{l}\text { Replacement } \\
\text { levels }(\%)\end{array}$} & $\begin{array}{l}\text { Average } \\
\left(\mathrm{N} / \mathrm{mm}^{2}\right)\end{array}$ & \multicolumn{2}{|c|}{ compressive } \\
\hline & 3 Days & 7 Days & 28 Days \\
\hline $0 \%$ & 8.34 & 17.12 & 27.28 \\
\hline $15 \%$ & 8.08 & 16.50 & 27.20 \\
\hline $17.5 \%$ & 7.92 & 16.30 & 26.9 \\
\hline $20 \%$ & 7.71 & 16.07 & 27.0 \\
\hline $22.5 \%$ & 7.5 & 15.74 & 27.27 \\
\hline $25 \%$ & 7.24 & 15.377 & 27.5 \\
\hline $27.5 \%$ & 7.00 & 15.066 & 26.06 \\
\hline $30 \%$ & 6.65 & 14.814 & 25.06 \\
\hline
\end{tabular}




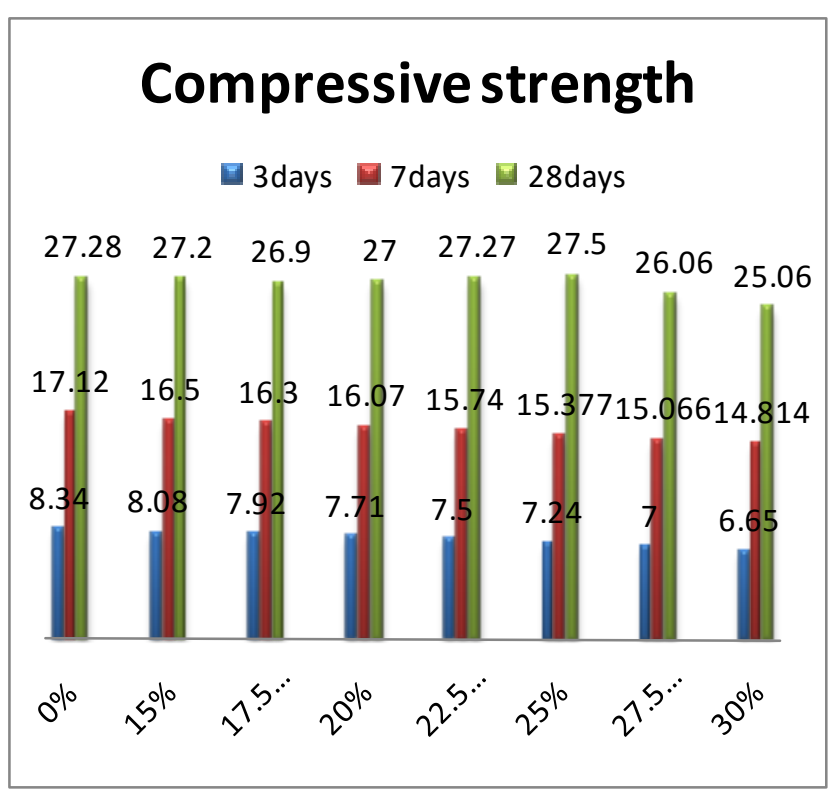

Chart -3: Compressive strength

Due to the low content of cement subsequently, it does not develop strength in the early stage, but shows almost equal reading of compressive strength for 28 days at a particular level of replacement. The above represented graph shows the maximum replacement levels as $25 \%$ for replacement of I.O.T and C.O.T.

\subsection{Tensile Strength}

Table -6: Details of average split tensile strength for 7, 14, and 28 days.

\begin{tabular}{|l|l|l|l|}
\hline \multirow{2}{*}{$\begin{array}{l}\text { Replacement } \\
\text { levels (\%) }\end{array}$} & $\begin{array}{l}\text { Average split tensile } \\
\left(\mathbf{N} / \mathbf{m m}^{2}\right)\end{array}$ & strength \\
\cline { 2 - 4 } & 7 Days & $\begin{array}{l}\text { 14 Days } \\
0 \%\end{array}$ & $\mathbf{2 8}$ Days \\
\hline $15 \%$ & 0.52 & 1.29 & 3.17 \\
\hline $17.5 \%$ & 0.49 & 1.25 & 3.19 \\
$20 \%$ & 0.45 & 1.21 & 3.20 \\
\hline $22.5 \%$ & 0.41 & 1.18 & 3.26 \\
\hline $25 \%$ & 0.36 & 1.11 & 3.30 \\
\hline $27.5 \%$ & 0.33 & 1.02 & 3.21 \\
\hline $30 \%$ & 0.30 & 0.99 & 3.01 \\
\hline
\end{tabular}

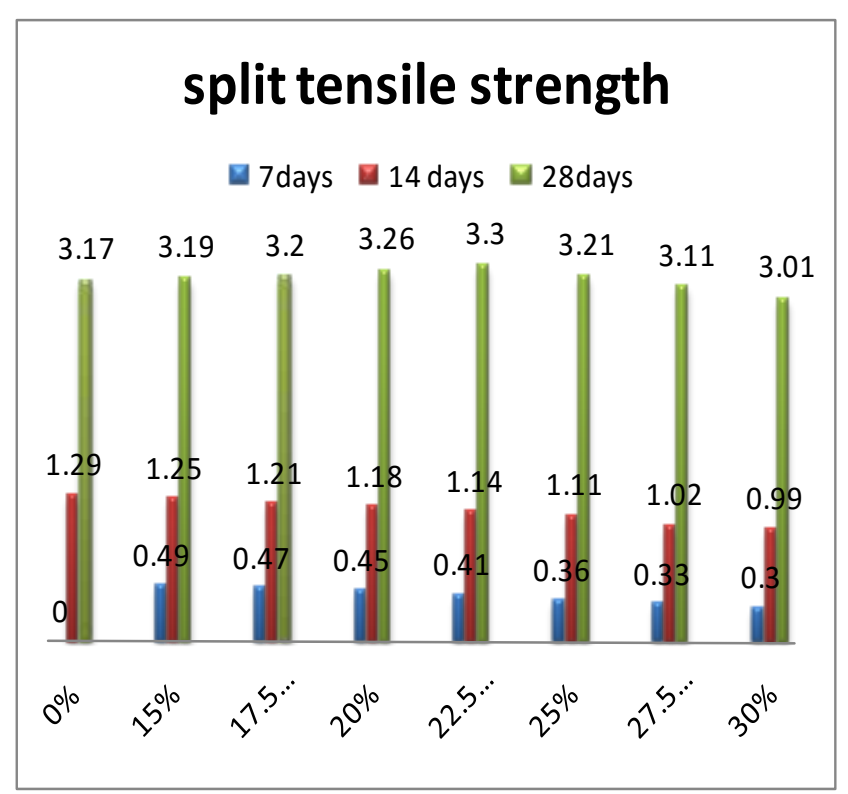

Chart -4: Tensile strength

Due to the low cement content subsequently, it does not develop strength in the early stage but it shows higher reading of tensile strength for 28 days at a particular level of replacement. The above represented graph shows maximum replacement level at $22.5 \%$ for replacement of I.O.T \& C.O.T,

\subsection{Flexural Strength}

Table -7: Details of average flexural strength for 28 and 56

\begin{tabular}{|l|l|l|}
\hline \multirow{2}{*}{$\begin{array}{l}\text { Replacement } \\
\text { levels (\%) }\end{array}$} & $\begin{array}{l}\text { Average } \\
\left(\mathbf{N} / \mathbf{m m}^{2}\right)\end{array}$ \\
\cline { 2 - 3 } & $\mathbf{2 8}$ Days & F6 Days \\
\hline $0 \%$ & 27.59 & 32.994 \\
$15 \%$ & 29.4 & 35.4 \\
\hline $17.5 \%$ & 31.994 & 36.2 \\
$20 \%$ & 33.99 & 37.2 \\
$22.5 \%$ & 34.81 & 40.8 \\
\hline $25 \%$ & 30.61 & 34.8 \\
\hline $27.5 \%$ & 26.2 & 31.8 \\
\hline $30 \%$ & 24 & 28.22 \\
\hline
\end{tabular}




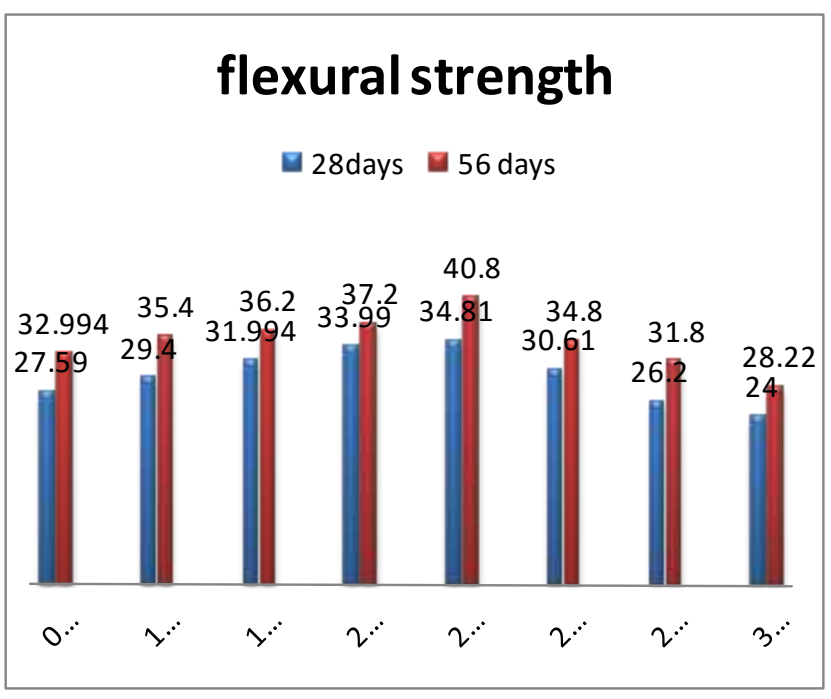

Chart -5: Flexural strength.

We can see the higher values of flexure with the increase of cement replacement by copper ore tailing and sand by iron ore tailing. Therefore the flexural strength is increased up to $22.5 \%$ replacement and after then it is decreased up to $30 \%$ replacement as Same as for 28days also.

So from graph 8.1, we getting the optimum flexural strength of concrete beam are $40.8 \mathrm{~N} / \mathrm{mm} 2$ at $22.5 \%$ replacement.

Compare to 28days strength 56 Days strength has increased by $14 \%$ at $22.5 \%$.

\section{CONCLUSION}

$>$ An attempt is made to use this copper ore tailing as an admixture in the preparation of fiber reinforced concrete by replacing the cement and iron ore tailing for sand in different percentages viz., 15, 17.5, 20, $22.5,25,27.5,30$ with percentage of $0.6 \%$ of steel fiber to the weight of cement. The fundamental property like compressive strength, tensile strength and flexural strength is determined.

$>$ The workability of concrete containing copper ore tailing and iron ore tailing content increases which is due to the higher water demand of concrete compared to conventional concrete.

$>$ Higher replacement of cement with copper ore tailing resulted in longer setting time of concrete mix.

$>$ As the replacement has increased results in the less unit weight.

$>$ The density of concrete decreases with increase in copper ore tailing content which lead to light weight concrete.

$>\quad$ The 7days and 14days strength of replaced concrete is less than conventional concrete but 28days strength is acceptably increased till $22.5 \%$, above which strength had decreased.

$>\quad$ The results show that concrete has significantly higher strength up to $22.5 \%$ replacement in M20 concrete.

$>$ Compressive strength, Tensile strength and flexural strength of the concrete has increased up to $22.5 \%$ with addition of copper ore tailing and iron ore tailing and after that it will decreased.

$>$ Addition of copper ore and iron ore tailing as pozzolanic material will enhance the property of concrete, reduces the cost of concrete production, and reduces the problem of its disposal and save the environment from the negative effects associated with the disposal of concrete.

$>$ From economic point of view, the percentage of cement replacement saves money.

$>\quad$ The possibility of developing low cost concrete using cooper and iron ore tailing is feasible with lower grades of concrete.

$>$ An attempt is made to use this copper ore tailing as an admixture in the preparation of fiber reinforced concrete by replacing the cement and iron ore tailing for sand in different percentages viz., 15, 17.5, 20, $22.5,25,27.5,30$ with percentage of $0.6 \%$ of steel fiber to the weight of cement. The fundamental property like compressive strength, tensile strength and flexural strength is determined.

$>\quad$ The results show that concrete has significantly higher strength up to $22.5 \%$ replacement in M20 concrete a 28 days.

\section{REFERENCES}

[1]. PrahalladaM. C. Dr. ShanthappaB.C,"Use of copper ore tailings - as an excellent pozzolana in the preparation of concrete" international journal of advanced research in engineering and applied sciences vol. 3, no. 3, march 2014. Page 42.

[2]. AnanthayyaM.B.PremakumarW.P,"Influence of steel fibers and partial replacement of sand by iron ore tailings on the compressive and splitting Tensile strength of concrete" international journal of civil engineering and technology volume 5, issue 3, march (2014), page 117-123.

[3]. ObinnaOnuaguluchi, "Copper tailings as a potential addictive in concrete: consistency, strength and toxic metal immobilization properties." Indian Journal of Engineering \& Materials Vol.19, April 2012, pp 79-86.

[4]. ObinnaOnuaguluchi and ÖzgürEren,"Rheology strength and durability properties of mortars containing copper tailings as a cement replacement material" European Journal of Environmental and Civil Engineering Vol. 17, No. 1, January 2013, page 19-31.

[5]. Hong-zhen KANG, Kai-wu JIA and WeihuaMA“Experimental Study on Compressive Strength and Elastic Modulus of Ferrous Mill Tailing Concrete"Journal of Engineering Science and Technology Review 6,may (2013), Page 123 - 128 .

[6]. Prahallada M. C.ShanmukaK.N, "Stabilized Iron-ore Tailings Blocks An- Environmental Friendly Construction Material"International Journal of IT, Engineering and Applied Sciences Research (IJIEASR)ISSN: 2319-4413 Volume 3, No. 4, April 2014, Page 222.

[7]. BlessenSkariah Thomas, AlokDamare, R.C. Gupta"Strength and durability characteristics of copper tailing concrete"Construction and Building Materials Volume 48, November 2013, Pages 894-900. 


\section{BIOGRAPHIES}

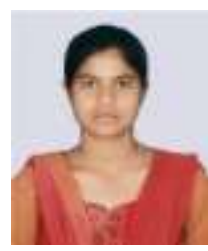

Ms. Chaithanya M.B is having her bachelor's degree in civil engineering from V.T.U, Belgaum and she is currently pursuing her masters in structural engineering from $\mathrm{S} J \mathrm{C}$ Institute of Technology, chickballapur.

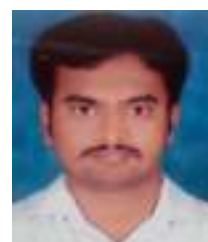

Mr. Shashi kumar N.V Assistant Professor, Department of civil engineering, S J C Institute of Technology, chickballapura. He has wide experience in teaching PH: 9972012406

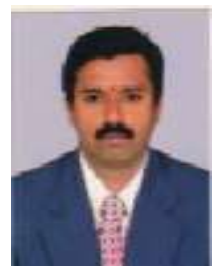

Dr. G. Narayana, Professor and Head of civil engineering department, S J C Institute of technology, Chickballapur, have a wide experience in teaching and research in the field of structural engineering. He is also a structural designer, consultant for many projects. PH: 9880923307

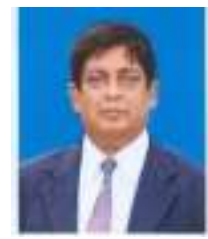

Dr. B.K Narendra, Principal, BGSIT. Bellur cross, have a wide experience in teaching and research in the field of structural engineering. $\mathrm{He}$ is also a structural designer, consultant for many projects.PH: 9880100556 